\title{
Can Islamic Finance Constitute A Solution to Crisis?
}

\author{
Hatem DERBEL \\ EconomiX, Paris West Nanterre la Défense University. \\ 200, Avenue de La République, 92000 Nanterre, France \\ Tel: 33-1-4097-7792Ｅ-mail: derbelhatem@yahoo.fr \\ Taoufik BOURAOUI \\ ESC Rennes School of Business \\ 2, Rue Robert d'Arbrissel - CS 76522 \\ 35065 Rennes Cedex - France \\ EconomiX, Paris West Nanterre la Défense University. \\ 200, Avenue de La République, 92000 Nanterre, France \\ Tel: 33-2-9933-4878 E-mail: taoufik.bouraoui@esc-rennes.fr \\ Neila DAMMAK \\ IRG, Paris East Créteil Val de Marne University \\ Route de Choisy - 94010 Créteil cedex - France \\ Tel: 33-1-4178-4767 E-mail: dammak_neila@yahoo.fr
}

Received: November 1, 2010

Accepted: November 16, 2010

doi:10.5539/ijef.v3n3p75

\begin{abstract}
The aim of this paper is to show that the Islamic finance is more stable than the conventional finance constituting, thus, a means to reduce the impact of financial crises. Using a VAR model for the financial indexes of France, United States, Indonesia and Saudi Arabia, we show that the effect of a shock on the American market during the period of crisis is negatively transmitted on all other markets, but with a small extent on the market using the method of Islamic financing.
\end{abstract}

Keywords: Islamic Finance, Financial crisis, VAR model

\section{Introduction}

If we exclude the introduction's trials of Islamic financial institutions in the mid of the 40s in Malaysia and in Pakistan at the end of the 50s, the first Islamic bank was established in 1963 in Mit Ghamr in Egypt (Sid Ahmed, 1982). However, the existence of this bank did not last for a long time and it was closed in 1967. It is only from the seventies where we noted the true launching of Islamic finance with the creation of the first Islamic banks, notably Islamic Development Bank (Jedda), Dubai Islamic Bank and Albaraka Banking Group (Bahrain).

Since, the Islamic financial institutions have developed in a remarkable way through several countries mainly in the Arab world (Saudi Arabia, Jordan, Dubai) and in Asia (Malaysia, Indonesia). From the 80s, Europe became interested in Islamic finance by opening in 1983 in Luxembourg the first insurance company (takaful) based on Islamic law, Chari'a, then by the creation of the first Islamic bank in 2004 which is The Islamic Bank of Britain. The aim of these financial institutions is the development and the promotion of new ways of financing in compliance with the precepts of Islam.

Nowadays, the area of Islamic finance is booming. According to a study established by an Islamic bank (Calyon), this market represents between 500 and 1000 billion dollars. Some products show an impressive growth as the Islamic bond market, the sukuks.

The development of this sector does not come only from the increase of the Muslim population immigrant or not, who is looking for financial products conform to Chari'a, but also from its efficiency and its performance. Several financial analyses show that Islamic finance constitutes an ethical choice that avoids the drift of speculation while reinstituting some values neglected by conventional finance, like trust. It prohibits not only investment in sectors considered "illicit" such as alcohol, pork, prostitution and gambling, but also it prohibits the payment of interest and speculation. Only investments in tangible assets are allowed. 
The Islamic finance market is attracting a great interest. With annual growth rates of $15-20 \%$ on overage over the last five years, it represents an international segment recording the fastest growth in the finance sector. This led us to be interested in this subject and to wonder us on the contribution of Islamic finance in comparison with the conventional finance. A big part of literature contains comparisons of instruments used in Islamic and conventional banking, and discusses the challenges of normalization and supervision linked to the Islamic banking (Sundararajan and Errico (2002); World Bank and FMI (2005); Ainley et al. (2007); Semelle (2007); Jobst (2007)).

However, there are very little empirical analysis on the role of Islamic finance in the financial stability. Some papers discuss the risks in Islamic financial institutions only in a theoretical framework, while empirical studies on Islamic banking are concentrated on issues linked to efficiency (Yudistira (2004); Moktar Abdullah and Al-Habshi-Habshi (2006)). Although several studies on Islamic finance have been developed, its role in financial stability has not yet been analyzed in a consistent, transnational and empirical way.

Our contribution in this paper is to lead an empirical study in order to check whether a finance based on Islamic law is more stable or not than a conventional finance. To this end, this paper is structured as follows: in section 2, we define Islamic finance and we present its operating rules. Section 3 discusses the relationship between Islamic finance and financial stability. In section 4 , we will conduct an empirical study to determine whether countries practicing Islamic finance were less affected or not by crisis in comparison with those who opt for traditional finance. Finally, section 5 concludes the paper.

\section{Islamic finance: Definition and basic principles}

The purpose of a financial system, whether it is conventional or Islamic, is the mobilization of financial resources and their allocation among various investment projects. However, the basic principles which govern an Islamic financial system are different from the spirit of conventional finance. If in the "classic" finance, the norm which chairs the decisions of an economic agent is to optimize the couple return - risk of its investments, the profitability is not the only nor the main criterion of decision for the Islamic operators.

Islamic finance is a financial system which relies primarily on Chari'a. This last is a set of laws and rules which govern in Islam the economic, social and political life. The existence of such system lies in the desire to ensure that financial products are compatible with legal and ethical principles of Islam.

The foundations of Islamic finance are based on 5 principles:

\subsection{The prohibition of riba (interest)}

Unlike conventional finance, Islamic finance prohibits riba. From the etymological point of view, the term riba comes from the Arab word "arba" which means to increase. This term refers to two distinct concepts in the terminology of conventional finance, namely the interest rate and usury. The first term indicates the amount paid for the use of money, whereas the second one refers to the offence committed by one who lends money at excessive rate. In the Muslim jurisprudence, the riba is defined as any pecuniary advantage or surplus perceived by one of the contractors without legitimately acceptable counterpart.

The prohibition of the practice of interest is not foreign for other religions. Indeed, it also prevailed among Christians and Jews. The prohibition of riba in Islam finds its origin in the Quran, the sacred book of Muslims and the main source of Islamic law. The Quran forbids expressly, in several times, the practice of riba. ... "O the believers! Fear Allah and abandon the usurious interest, if you are believers." Quran, Sura 2, Verse 278. There are several forms of riba, but the most common form is called riba an-nassia, which concerns the monetary surplus or interests required by contract as part of a credit.

\subsection{The prohibition of gharar (incertainty) and maysir (speculation and random)}

Muslim jurisprudence prohibits the uncertainty in the terms of a contractual relationship. The concept of gharar refers to any exchange in which there is an imprecise, ambiguous, or uncertain element. That includes not only trade in goods that the salesman is not in position to sell, but also the contracts which depend on an unpredictable event. The uncertainty in case of sale of a future product consists in the impossibility of predicting the quality and/or the quantity of the sold product. This last must be clearly defined and known so that the sale is valid and so that there is no hazard.

It should be noted that goods, the object of the exchange, should not necessarily exist at the time of the signing of contract. Thus, the forward sale is not condemned. The transaction is in conflict with the Chari'a principles only if the terms of the exchange are conditional on a dubious future event which does not depend on the contractors. 
The maysir is defined as any form of contract in which the right of the contracting parties depends on a random event, such as gambling. The operations which rest on pure speculation in order to carry out a profit are illicit (haram) and thus are prohibited in Islamic law.

\subsection{The prohibition of investment in haram (illicit) activities}

Islamic finance prohibits investment in the illicit economic activities. The financed assets must be halal, i.e. relative to an activity in conformity with Chari'a, which exclude for example the activities related to the sectors like alcohol, the armament, the pornography,... etc.

\subsection{Tangibility of assets}

According to the rules of Chari'a, any financial transaction must be leaned with a tangible asset (like a real estate for example). So, financial products such as subprime mortgages can not be created in this system. This principle, also known as asset-backing moves aside the possibility for a firm to ask a banking establishment to open a simple line of credit.

\subsection{Sharing of profits and losses}

Islamic finance has a particular vision on sharing profits and losses between the different stakeholders in a financial transaction. It advocates an equitable sharing of profits and risks between the investor (the lender) and the contractor (the borrower) whatever the form of financing used. A financial transaction that transfers all the risks associated to an investment project on a single stakeholder is, therefore, contrary to the principles of Chari'a. Sharing arrangements must be agreed at the signing of the contract by determining a percentage of loss or gain.

\section{Financial crisis and Islamic finance}

The financial crisis which was triggered in 2006 by a crash of the subprime mortgages in the United States, and revealed to the world in February 2007, then transformed into international financial crisis since August 2007 is considered as the most serious of the post-war period. It did not only affect the mortgage credits granted to the risky American households, but it was propagated towards the banking and financial system. It has crippled the financial systems of several countries and caused the disappearance of the major financial institutions. The crisis has shown that conventional finance is very vulnerable and unable to survive alone. Islamic finance has been erected as an alternative to the conventional financial system.

However, the debate on the relationship between Islamic finance and stability during the period of subprime crisis is with double edge. On the one hand, several financial analysts consider that the Islamic finance, by its nature, is more stable than the conventional finance (Moody's (2008), Bouslama.G (2008), Drown.C (2009). Indeed, in conventional finance, the proliferation of financial innovations in deregulated markets has led to a massive monetary creation with a very thin real basis. The excessive use of models of securitization made difficult to understand the characteristics of new products in terms of risk. The central bank may also play a crucial role in financial instability if it allows an expansion of the credit not sustained by adequate resources, i.e. a credit growth without a sufficient growth of the saving in the system. So the central bank allows, through its monetary policy, the banks to be involved in an expansion of credit without counterpart (in terms of savings). In fact, it is not the expansion of the credit which can result in a crisis situation, but it is the expansion of credit without counterpart which leads to a diversion of the real saving from the productive activities towards the non-productive activities, which in its turn weakens the creative process of real wealth. The absence of these devices in Islamic finance made this type of financing a more stable system. The prohibition of interest and devices of sharing profits and losses create a financial system based on reel assets. Consequently, banks cannot initiate or accentuate a speculative process. The credit is based on real savings and this one can release an output only if it is directly invested in productive activities. The banks are competed only for the real investment and their resources are reinvested in real activities. As a result, economic growth is durable and does not contain negative impact on social justice since inflation cannot be used to impoverish creditors and employees and to enrich debtors and speculators.

In addition, deposits in a bank cannot be transformed into loans or used to buy financial assets and become reserves or a base for a new loan at another bank, contributing thus to a creation of purchasing power and to inflation. The deposits must be reinvested directly by the bank in production and trade activities.

The Islamic financial system is a system where there are no assets without risk and where all the transactions are based on the sharing of profits or losses. The contracts like futures, options, swaps are prohibited because their realizations are characterized by an obvious uncertainty. However, the operations and the products of Islamic finance are not only strongly leaned and closely related to the real economic sphere but also completely independent and are disconnected from the traditional financial sphere. This has the effect of reducing uncertainty, duct savings 
towards the real and material investments, and the completely elimination of speculation and its effects which, often, distort economic predictions, skew the prices of goods and inflate the consequences of a possible crisis.

In Islamic finance, interest rate is not used as monetary policy instrument. The central bank does not refinance the banks, and does not provide financial instruments to the banks as it is the case in conventional finance. The central bank applies quantitative ceilings on the monetary aggregates. Such a policy was effective in maintaining financial stability and in the exclusion of speculative booms and inflation.

The sources of financial instability of the conventional system, i.e. the abundance of liquidities, the credit without counterpart, the speculation and the fixing of interest rate by the central bank are absent in Islamic finance, ensuring, thus, the stability of this system. A finance based on the rules of Chari'a condemns the interest which encourages the polarization of money in the hands of minority, but institutes, in compensation, the sense of sharing and equitable redistribution of wealth.

On the other hand, other financial analysts consider that Islamic banks are unstable and may lead to many risks in the financial system that differ from those of conventional banks, such as liquidity risk, operational risk and legal risk. Choong and Liu (2006) argue that Islamic banking services, at least as practised in Malaysia, diverge from the sharing of profits and losses principle, and in practice are not very different from the traditional system. Their results suggest that the quick growth in Islamic banking sector is principally fed by the revival of Islam in the world rather than by the advantages of the sharing of profits and losses principle, and that Islamic banks should be regulated in a similar way as their western counterparts.

The prohibition of interest may result in the underdevelopment of funding sources. Thus, Islamic banks face specific obstacles in the management of liquidity. Moreover, as indicated by Noyer.C (2009), the weakness of standardization of the products and the lack of harmonization of Islamic norms, due to differences between the interpretations of the Chari'a specialists, may increase the operational risk and legal uncertainty making, thus, the follow-up of the sharing of profits and losses principle much more complex as the volume of the bank transactions increases. Similarly, the prohibition to finance certain sectors limits the categories of assets eligible for investments, which contributes to increase the risk of concentration in sectors more sensitive to the conjuncture. In the same context, Cihák.M and Hesse.H (2008) show that the more the size of the Islamic banks increases, the more they find difficulties of adjusting their monitoring systems of the credit risk. They also note that the market share of Islamic banks has no significant impact on the financial strength of other banks.

The analysis of the principles of Islamic finance does not allow, alone, resolving the question of the relationship between Islamic finance and financial stability. It is necessary to supplement them by an empirical analysis. For this reason, we will conduct an empirical study to check whether countries practicing Islamic finance were relatively less affected by the crisis than those using the conventional method of financing.

\section{Empirical study}

\subsection{Data and methodology}

Our purpose in this empirical section is to determine whether Islamic finance is able to absorb shocks in the context of a global economy very disturbed by the world financial crisis. To do this, we use a model VAR including a sample of 4 market indexes: France (CAC40), the USA (NASDAQ), Indonesia (JAKISLM) and Saudi Arabia (TADAWUL). The data, collected from Datastream, are daily frequencies and cover the period from 16/07/1997 to $15 / 12 / 2009$.

\subsection{Descriptive study}

According to Fig.1, we note that all series in level have an upward trend which disappears when the series are in first difference. All series of the market indexes relating to the United States, France, Saudi Arabia and Indonesia, are a priori non-stationary.

Insert Figure1 here.

\subsection{Unit Root test}

To study the stationarity of variables, we use the Augmented Dickey-Fuller test (ADF). Table 1 reports the results of this test. These results show that all the market indexes are non-stationary in level, but stationary in first difference and, consequently, they are integrated of order one (I (1)).

Insert Table 1 here.

\subsection{The cointegration test}

The unit root test indicates that all the series of market indexes exhibit the same order of integration. According to the terminology of Engel and Granger (1987), there may be a possible long-term stable relationship between these 
variables. To test cointegration, we use the approach of Johansen (1995). The first stage of this analysis is to determine the number of gap of the autoregressive vectorial model (i.e. VAR (p)). To do this, we estimate some numbers of autoregressive processes and we retain the one that jointly minimizes the criteria of Akaike and Schwartz. Table 2 presents the overall results.

Insert Table 2 here.

The minimization of the Akaike criterion led to retain 4 gaps, whereas for the Schwartz criterion, that leads us to retain two gaps. According to the principle of parsimony, we adopt two gaps $(\mathrm{P}=2)$. From table 2, we can conclude that this is a VAR model of order (2). Johansen (1995) proposed a test based on the vectors corresponding to the highest eigenvalues of the matrix model presented by equation (1):

$$
\Delta X_{t}=\delta_{0}+\Pi X_{t-1}+\delta_{1} \Delta X_{t-1}+\mu_{t} \quad \mathrm{t}=1, \ldots, \mathrm{T} .
$$

Where : $X_{t}$ : the vector of dimension $(\mathrm{k} \times 1)$ which contains current and lagged values of $\mathrm{K}$ variables; $\Delta:$ the operator of first difference; $\delta_{0}$ : the matrix of dimension parameters $(\mathrm{k} \times 1) ; \delta_{1}$ : the matrix of dimension parameters $(\mathrm{k} \times \mathrm{k}) ; \mu_{t}$ : the vector of random errors; $\Pi$ : the matrix which determines the number of cointegrating relationships.

From the eigenvalues of the matrix $(\Pi)$, Johansen statistic can then be determined. The results of tests are based on the comparison of the statistic LR (likelihood ratio) with the critical values at 5\% level. If this statistic is higher than these values, we conclude that there is at least one cointegration relationship between variables; otherwise, no relationship of cointegration exists between them. The results of the trace used to determine the rank of cointegration are presented in table 3 below:

Insert Table 3 here.

The exam of this table shows that there is no cointegration relationship. Before estimating our model, we conduct the causality test of Granger to examine not only the interdependance between markets, but also to specify the sense of causality.

\subsection{The causality test}

To better specify the nature of short-term dynamics and the sense of causality, we used the causality test of Granger (1969). The causality test specifies the short-term relationship and indicates which of the variables has an impact on the other. The results of the Granger causality tests are reproduced in table 4.

Insert Table 4 here.

In light of the results of Granger causality tests, we observe bidirectional causality between the couples of markets (France, the United States), (France, Saudi Arabia), and (Saudi Arabia, Indonesia). However, we note the presence of unidirectional causality from the U.S market to the markets of Saudi Arabia and Indonesia and also from France to Indonesia.

The absence of cointegration between nonstationary series and the existence of causalities between the series stationary in first difference, leads us to estimate a model VAR in difference.

\subsection{Estimation of the model}

The estimations are provided by the Eviews software. The found results are better analyzed by using response functions to a shock. In this paper, we are only interested in analyzing the impact which a shock could have on the US market on the other markets. This shock, occurring in one period, is not maintained. But, since the model includes an autoregressive and an economic dynamic, through functions of reaction, the shock persists in attenuated form during some time. The initial positive shock on the NASDAQ tends to be reduced gradually as other markets take it into account later in their functions of reaction.

- We note first that the effect of the shock on Nasdaq is more important in the markets where finance is conventional (about 0.02 in the U.S and 0.11 in France) in relation to those where finance is Islamic (about 0.04).

- We also note that the shock on the Nasdaq is transmitted negatively on all other markets but with a different extent. In France, we observe a continuous decrease of the CAC40, which becomes negative after two periods and a half. This last reaches its minimum on the level of the 3 rd period $(-0,003)$. A reversal of the trend is also noted. Indeed, it reaches a positive sign but very weak on the fourth period and then decreases again to have a negative sign during the fifth period. In the U.S, almost the same trend was observed. Indeed, we notice a continuous reduction of the index which reaches its minimum at the end of the 2 nd period $(-0,004)$, then it increases while remaining negative before the effect of the shock fades. On the other hand, in Saudi Arabia and Indonesia, we note, at the beginning, a positive effect during the first two periods, and then the indexes start to decrease gradually to reach a minimum during the fourth period of about -0.0001 . 
In the light of this work, it is clear that the current financial crisis was transmitted negatively on all the markets. This effect is of weak extent in the markets where finance is Islamic. Consequently, Islamic finance can constitute an effective additional financing system beside conventional finance in the Western countries in order to reduce the effect of crises.

\section{Conclusion}

The purpose of this paper is to highlight the benefits of Islamic finance. Theoretically, several studies have shown that this type of financing can reduce the effect of crises. In order to illustrate this report empirically, we used an econometric model, specially a VAR model for the case of the financial markets of the United States, France, Saudi Arabia and Indonesia. The results show that the transmission of the current crisis is weak in the markets which are based on Islamic finance. Indeed, regarding the extent of the effect, we noted that the reduction in indexes is more important in the United States and in France compared to those in Saudi Arabia and in Indonesia. So, the negative effect of the shock is more important in the markets where finance is conventional.

Unlike conventional finance which is periodically hit by crises of varying severity, Islamic finance can be regarded as a stable and efficient financial system to absorb shocks, and able to promote growth and job creation. Nevertheless, juridical and fiscal adjustments are necessary to accelerate its development.

\section{References}

Abdelkader.S.A. (1982). Islamic finance and development, Revue du tiers monde 23, 877-890. (in French)

Abdelkader.S.A. (1990). Islamic economic, principles and reality: the recent experience of Arabic countries. A first evaluation, Revue du tiers monde 31, 405-435. (in French)

Ainley.M, Mashayekhi,A, Hicks.H, Arshadur.R \& Ravalia.A. (2007). Islamic Finance in the UK: Regulation and Challenges, Financial Services Authority, London.

Banque mondiale \& FMI. (2005). Financial Sector Assessment, Handbook, Washington, Worldbank.

Bouslama.G. (2008). The islamic finance: a survivor of subprimes' tsunami?, Banque Stratégie 264, 36-38. (in French)

Choong. B.S \& Liu. M.H. (2006). Islamic Banking: Interest-Free or Interest Based? Available at SSRN: http://ssrn.com/abstract=868567.

Cihak. M \& Hesse.H. (2008). Islamic Banks and Financial Stability: An Empirical Analysis, International Monetary Fund, Working Paper WP/08/16.

Dennis.O \& Taisier.Z.A. (2008). Using accounting ratios to distinguish between Islamic and conventional banks in the GCC region, The International Journal of Accounting 43, 45-65.

Dickey.D.A \& Fuller.W.A. (1979). Distribution of the Estimators for Autoregressive Time Series with a Unit Root, Journal of the American Statistical Association 74, 427-431.

Engel.R.F \& Granger.C.W.J. (1987). Cointegration and Error Correction: Representation, Estimation and Testing" Econometrica 55, 251-276.

Granger.C.W. (1969). Investigating Causal Relations by Econometric Models and Cross Spectral Methods, Econometrica 37, 424-438.

Jobst.A. (2007). The Economics of Islamic Finance and Securitization, IMF Working Paper $\mathrm{N}^{\circ}$ 07/117 Washington: International Monetary Fund.

Johansen.S. (1995). Likelihood-Based Inference in Cointegrated Vector Autoregressive Models, New York: Oxford University Presss.

Krichene.N \& Saidane.E. (2009). Resilience and stability of Islamic finance, Available: http://www.webmanagercenter.com/management/article.php?id=71657

Moktar.A, Hamim.S, Naziruddin.A \& Al-Habshi.S.M. (2006). Efficiency of Islamic Banks in Malaysia: A Stochastic Frontier Approach, Journal of Economic Cooperation among Islamic Countries 27, 37-70.

Moody's Investors Services. (2008). Gulf Islamic Banks Resilient Amid Global Credit Woes, Special Comment. Report published Nov 27, 2008, USA

Noyer.C. (2009). World stability, the future of capital markets and the Islamic finance in France; Seminar Euromoney, Conference on Islamic finance, Paris 29, 30 September 2009,. (in French) 
Sundararajan.V \& Errico.L. (2002). Islamic Financial Institutions and Products in the Global Financial System: Key Issues in Risk Management and Challenges Ahead, IMF Working Paper 02/192,. 1-28. Available at SSRN: http://ssrn.com/abstract=880303.

Yudistira.D. 2004). Efficiency in Islamic Banking: An Empirical Analysis of Eighteen Banks, Islamic Economic Studies 12, 1-19.

Table 1. Unit Root test

\begin{tabular}{|c|c|c|c|c|c|c|}
\hline & Lag & Model $^{*}$ & Stat ADF & & $\mathbf{T}_{\mathrm{ADF}}$ & Process \\
\hline & & & & $1 \%$ & -2.568632 & \\
\hline \multirow[t]{3}{*}{ LCAC40 } & \multirow[t]{3}{*}{1} & \multirow[t]{3}{*}{3} & \multirow{3}{*}{-0.976070} & $5 \%$ & -1.941326 & \multirow[t]{3}{*}{ DS } \\
\hline & & & & $10 \%$ & -1.616362 & \\
\hline & & & & $1 \%$ & -2.568338 & \\
\hline \multirow[t]{3}{*}{ DLCAC40 } & \multirow[t]{3}{*}{1} & \multirow[t]{3}{*}{3} & \multirow{3}{*}{-27.65925} & $5 \%$ & -1.941326 & \multirow[t]{3}{*}{ Stationary } \\
\hline & & & & $10 \%$ & -1.616361 & \\
\hline & & & & $1 \%$ & -2.568638 & \\
\hline \multirow[t]{3}{*}{ LJAKISLM } & \multirow[t]{3}{*}{1} & \multirow[t]{3}{*}{3} & \multirow{3}{*}{0.068512} & $5 \%$ & -1.941326 & \multirow[t]{3}{*}{ DS } \\
\hline & & & & $10 \%$ & -1.616361 & \\
\hline & & & & $1 \%$ & -2.568638 & \\
\hline \multirow[t]{3}{*}{ DLJAKISLM } & \multirow[t]{3}{*}{1} & \multirow[t]{3}{*}{3} & \multirow{3}{*}{-22.08991} & $5 \%$ & -1.941326 & \multirow[t]{3}{*}{ Stationary } \\
\hline & & & & $10 \%$ & -1.616361 & \\
\hline & & & & $1 \%$ & -2.568644 & \\
\hline \multirow[t]{3}{*}{ LNASDAQ } & \multirow[t]{3}{*}{2} & \multirow[t]{3}{*}{3} & \multirow{3}{*}{-0.336583} & $5 \%$ & -1.941327 & \multirow[t]{3}{*}{ DS } \\
\hline & & & & $10 \%$ & -1.616361 & \\
\hline & & & & $1 \%$ & -2.568644 & \\
\hline \multirow[t]{3}{*}{ DLNASDAQ } & \multirow[t]{3}{*}{2} & \multirow[t]{3}{*}{3} & \multirow{3}{*}{-20.99520} & $5 \%$ & -1.941327 & \multirow[t]{3}{*}{ Stationary } \\
\hline & & & & $10 \%$ & -1.616361 & \\
\hline & & & & $1 \%$ & -2.568232 & \\
\hline \multirow[t]{3}{*}{ LTADAWUL } & \multirow[t]{3}{*}{1} & \multirow[t]{3}{*}{3} & 0401601 & $5 \%$ & -1.941326 & DS \\
\hline & & & -0.401681 & $10 \%$ & -1.616362 & \\
\hline & & & & $1 \%$ & -2.568638 & \\
\hline DLTADAWUL & 1 & 3 & 2207040 & $5 \%$ & -1.941326 & Stationary \\
\hline & & & $-22.9 / 048$ & $10 \%$ & -1.616361 & \\
\hline
\end{tabular}

(1): Model with intercept and trend

(2): Model with intercept

(3): Model none

Table 2. Number of gaps

\begin{tabular}{|l|c|c|c|c|c|}
\hline & $\mathrm{P}=1$ & $\mathrm{P}=2$ & $\mathrm{P}=3$ & $\mathrm{P}=4$ & $\mathrm{P}=5$ \\
\hline Akaike information criterion & -20.23635 & -20.68751 & -20.72651 & $\mathbf{- 2 0 . 7 3 9 7 7}$ & -20.70307 \\
\hline Schwarz criterion & -20.09539 & $\mathbf{- 2 0 . 4 3 3 4 6}$ & -20.35911 & -20.25873 & -20.10811 \\
\hline
\end{tabular}


Table 3. Test of cointegration

Date: 01/19/10 Time: 00:02

Sample (adjusted): 7/18/2007 12/15/2009

Included observations: 630 after adjustments

Trend assumption: Linear deterministic trend

Series: LNASDAQ LCAC40 LTADAWUL LJAKISLM

Lags interval (in first differences): 1 to 1

Unrestricted Cointegration Rank Test (Trace)

\begin{tabular}{ccccc}
\hline $\begin{array}{c}\text { Hypothesized } \\
\text { No. of CE(s) }\end{array}$ & Eigenvalue & $\begin{array}{c}\text { Trace } \\
\text { Statistic }\end{array}$ & $\begin{array}{c}0.05 \\
\text { Critical Value }\end{array}$ & Prob.** \\
\hline None & 0.027487 & 39.27138 & 47.85613 & 0.2496 \\
At most 1 & 0.019252 & 21.71207 & 29.79707 & 0.3148 \\
At most 2 & 0.010784 & 9.464890 & 15.49471 & 0.3241 \\
At most 3 & 0.004172 & 2.633763 & 3.841466 & 0.1046 \\
\hline
\end{tabular}

Trace test indicates no cointegration at the 0.05 level

* denotes rejection of the hypothesis at the 0.05 level

**Mackinnon-Haug-Michelis (1999) p-values

Table 4. Granger causality tests

Pairwise Granger Causality Tests

Date: 01/19/10 Time: 00:12

Sample: 7/16/2007 12/15/2009

Lags: 1

\begin{tabular}{lccr}
\hline Null Hypothesis: & Obs & F-Statistic & Prob. \\
\hline DLCAC40 does not Granger Cause DLNASDAQ & 631 & 4.12667 & 0.0426 \\
DLNASDAQ does not Granger Cause DLCAC40 & & 133.716 & $4 . E-28$ \\
\hline DLTADAWUL does not Granger Cause DLNASDAQ & 631 & 0.51034 & 0.4753 \\
DLNASDAQ does not Granger Cause DLTADAWUL & & 45.3494 & 4. E-11 \\
\hline DLJAKISLM does not Granger Cause DLNASDAQ & 631 & 0.07651 & 0.7822 \\
DLNASDAQ does not Granger Cause DLJAKISLM & & 61.4935 & 2. E-14 \\
\hline DLTADAWUL does not Granger Cause DLCAC40 & 631 & 14.8207 & 0.0001 \\
DLCAC40 does not Granger Cause DLTADAWUL & & 23.4525 & 2. E-06 \\
\hline DLJAKISLM does not Granger Cause DLCAC40 & 631 & 1.61708 & 0.2040 \\
DLCAC40 does not Granger Cause DLJAKISLM & & 31.8476 & $3 . E-08$ \\
\hline DLJAKISLM does not Granger Cause DLTADAWUL & 631 & 9.16746 & 0.0026 \\
DLTADAWUL does not Granger Cause DLJAKISLM & & 6.72257 & 0.0097 \\
\hline
\end{tabular}





LTADAWUL

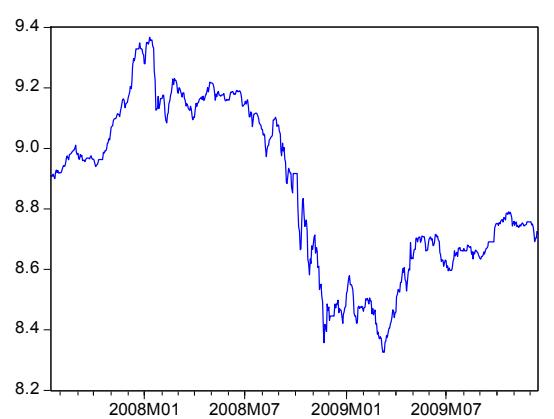

DLTADAWUL

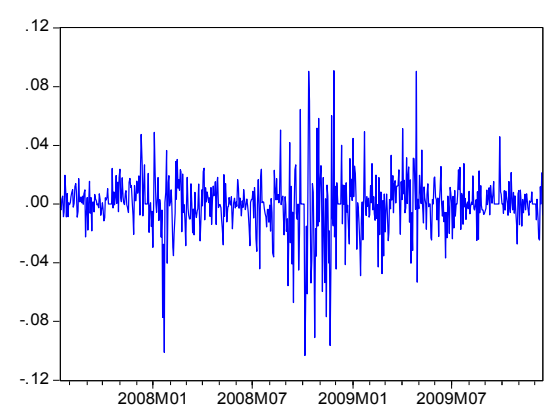

LJAKISLM

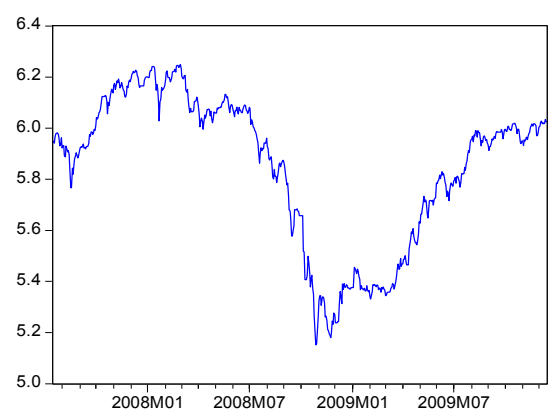

DLJAKISLM

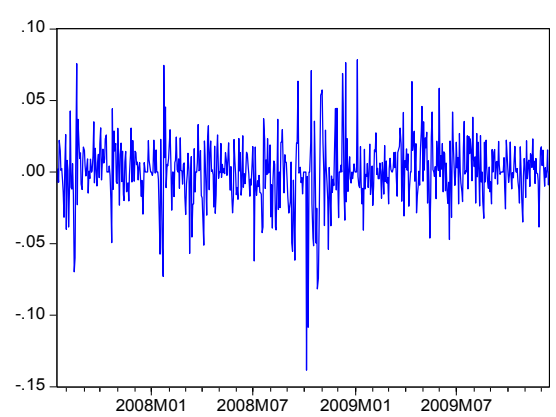

Figure1. Descriptive Study 